\title{
Perancangan Sistem Informasi Peminjaman dan Pengembalian Rekam Medis Rawat Jalan di Rumah Sakit Muhammadiyah Bandung
}

\author{
Israwati $^{1}$, Sali Setiatin ${ }^{2}$, Falaah Abdussalaam ${ }^{3}$ \\ ${ }^{1,2}$ Program Studi D3 Rekam Medis dan Informasi Kesehatan, Politeknik Piksi Ganesha Bandung \\ ${ }^{3}$ Program Studi D3Manajemen Informatika, Politeknik Piksi Ganesha Bandung
}

\begin{tabular}{l} 
Article Info \\
\hline Article history: \\
Received Jun 28, 2021 \\
Revised Jul 22, 2021 \\
Accepted August 23, 2021 \\
\hline
\end{tabular}

\section{Keywords:}

Information Systems

Borrowing And Returning

Medical Records

Waterfall

Visual Studio 2010

\begin{abstract}
This research was conducted based on the problem of managing the borrowing and returning outpatient medical records at the Muhammadiyah Hospital Bandung which aims to find solutions to these problems to support the effectiveness of medical record services. The research method used in this research is a qualitative method with a descriptive approach. The data collection techniques usedwereinterviews, observation, and study approach. In making the software design the writer uses the waterfall method and the supporting applications used are Microsoft Visual Studio 2010 and Microsoft Access 2013. From the results of the research conducted, the authors found several problems in the management of borrowing and returning outpatient medical records, namely: (1). There were no medical records found on the storage shelf; (2). Recording of borrowing and returning medical records still uses a manual system; (3). The absence of reports on borrowing and returning medical records. The suggestions that can be given by the author, namely: (1). It is better if the borrowing of medical records is determined by the due date so that there are no more medical records that are late to be returned to the storage room; (2). An information system is needed on borrowing and returning medical records to support activities in the hospital, especially in making reports on borrowing and returning medical records. The result of this research is an information system for borrowing and returning medical record files at Muhammadiyah Hospital Bandung. This information system is integrated with SIMRS application, making it easier to check patient visit history and facilitate officers in the process of borrowing and finding medical records that are not found in the storage room so that the process of borrowing and returning medical records can be well controlled.
\end{abstract}

This is an open access article under the CC BY-SAlicense.

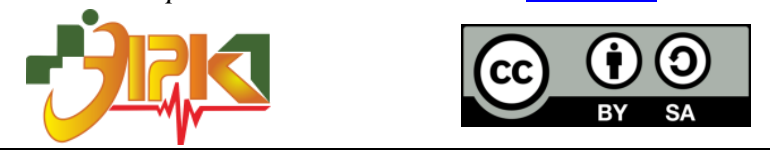

Corresponding Author:

Israwati,

Program Studi D-3 Rekam Medis dan Informasi Kesehatan,

Politeknik Piksi Ganesha Bandung,

Jl. Gatot Subroto No.301, Maleer, Kec. Batununggal, Kota Bandung-Jawa Barat.

Email: icisrawaty@gmail 


\section{PENDAHULUAN}

Rumah sakit merupakan institusi pelayanan kesehatan yang menyelenggarakan pelayanan kesehatan perseorangan dengan cara paripurna yang menyediakan pelayanan rawat inap, rawat jalan dan gawat darurat, serta institusi pelayanan kesehatan bagi masyarakat dengan karateristik tertentu yang dipengaruhi oleh pertumbuhan ilmu pengetahuan kesehatan, kemajuan teknologi, serta kehidupan sosial ekonomi warga yang wajib senantiasa dapat menaikkan pelayanan yang lebih bermutu serta terjangkau oleh warga supaya terwujud derajat kesehatan yang setinggi-tingginya [1]. Selain itu Rumah Sakit dapat berfungsi sebagai tempat pendidikan dan penelitian bagi tenaga kesehatan.

Salah satu sarana yang menunjang penyelenggaraan pelayanan kesehatan di rumah sakit adalah penyelenggaraan rekam medis. Rekam medis merupakan berkas yang berisikan catatan serta dokumen tentang bukti diri penderita, pengecekan, penyembuhan, tindakan serta pelayanan lain yang sudah diberikan kepada penderita [2]. Catatan ialah tulisan-tulisan yang dibuat oleh dokter ataupun dokter gigi perihal tindakan-tindakan yang diberikan kepada penderita dalam rangka pelayanan kesehatan. Rekam medis pasien harus siap apabila pasien berobat kembali. Tenaga kesehatan bakal kesulitan dalam melakukan pengobatan sebelum mengetahui riwayat penyakit, tindakan maupun terapi yang dilakukan kepada penderita yang terdapat dalam dokumen rekam medis. Perihal penting dalam rekam medis adalah ketersediannya saat dibutuhkan pengisiannya. Kegunaan dari rekam medis itu sendiri bisa dilihat dari bermacam aspek ialah aspek administrasi, aspek hukum, aspek riset, pembelajaran serta dokumentasi, pelayanan rekam medis di rumah sakit meliputi registrasi pasien sampai penyelenggaraan penyimpanan dokumen rekam medis [3].

Kegunaan rekam medis tersebut menjadikan rekam medis selalu dipinjam dari ruang penyimpanan rekam medis. Maka, supaya rekam medis bisa diketahui keberadaannya serta terpelihara kerahasiaannya, diperlukan suatu catatan peminjaman dan pengembalian rekam medis yang dikenal dengan buku ekspedisi. Buku ekspedisi merupakan buku panduan untuk mengetahui serta mengawasi rekam medis yang lagi dipinjam maupun yang telah dikembalikan [4].

Peminjaman rekam medis adalah kegiatan meminjam berkas rekam medis oleh dokter untuk kepentingan tindak lanjut penelitian. Ketentuan mengenai peminjaman ialah semua berkas rekam medis yang keluar dari ruangan rekam medis wajib dicatat pada tracer dan semua rekam medis rawat jalan wajib kembali dalam waktu 1x24 jam, di luar ketentuan tersebut perawat atau dokter yang masih memerlukan rekam medis, harus memberitahukan petugas rekam medis rawat jalan. Peminjaman rekam medis untuk kepentingan penelitian serta pendidikan dikerjakan di ruang rekam medis. Untuk peminjaman IGD dan rawat inap berlaku jam pengembilan. Peminjaman serta pengembalian rekam medis wajib dikendalikan dan dikontrol dengan tepat untuk mengurangi kehilangan dokumen rekam medis dan terjadinya missfile [4].

Berdasarkan hasil penelitian yang dilakukan di Rumah Sakit Muhammadiyah Bandung menunjukkan bahwa pengelolaan peminjaman serta pengembalian rekam medis tidak berjalan sesuai Standar Operasional Prosedur (SOP) yang berlaku, dimana berkas rekam medis yang di pinjam tidak dicatat di buku ekspedisi sehingga mengakibatkan tidak diketahuinya berkas rekam medis mana saja yang dipinjam. Saat ini peminjaman rekam medis masih disesuaikan dari sistem pendaftaran masuk dari database yang sudah ada, disamping itu ada rekam medis yang masih berada di poliklinik dan belum kembali ke ruangan rekam medis lebih dari 1×24 jam, sehingga ketika pasien datang berobat, rekam medis tidak ditemukan dalam penyimpanan sehingga kadang petugas mengira berkas rekam medis salah masuk rak filling. Hal tersebut disebabkan petugas tidak memakai tracer untuk mengetahui dokumen yang sedang dipinjam, sehingga mempersulit petugas dalam melaksanakan pencarian dokumen yang keluar dari rak filling dan mempersulit 
petugas ketika mengembalikan dokumen rekam medis, serta belum tersedianya sistem informasi peminjaman serta pengembalian berkas rekam medis. Sistem informasi pada zaman sekarang sangat diperlukan, sebab bisa berguna untuk memudahkan petugas peyimpanan untuk mengawasi maupun mengatur berkas rekam medis yang dipinjam telah dikembalikan atau belum [5]. Serta sistem informasi ini berfungsi agar kedepannya rekam medis yang dipinjam atau belum kembali dapat diketahui dari awal dan dapat segera diambil pada hari itu juga sebelum dilakukannya pencarian rekam medis.

Berdasarkan fakta-fakta yang telah di deskripsikan, maka penulis tertarik untuk "Merancangan Sistem Informasi Peminjaman dan Pengembalian Rekam Medis Rawat Jalan Menggunakan Microsoft Visual Studio 2010 di Rumah Sakit Muhammadiyah Bandung" yang bertujuan untuk memudahkan petugas dalam penulisan, peminjaman, pengembalian, mengawasi dan mengendalikan rekam medis.

\section{METODE PENELITIAN}

Metode pengumpulan data yang dilakukan dalam penelitian ini merupakan metode penelitian kualitatif melalui pendekatan deskriptif, yang menganalisis dan menggambarkan objek penelitian yaitu prosedur peminjaman serta pengembalian rekam medis pasien rawat jalan di Rumah Sakit Muhammadiyah Bandung. Penelitian kualitatif adalah penelitian tentang riset yang bersifat deskirptif dan cenderung menggunakan analisis dengan pendekatan induktif. Proses dan makna (prospektif subyek) lebih difokuskan dalam penelitian kualitatif [6]. Landasan teori digunakan sebagai pemandu supaya fokus penelitian sesuai dengan fakta di lapangan. Tidak hanya itu landasan teori pula berguna untuk memberikan cerminan umum mengenai latar belakang riset serta sebagai bahan pembahasan hasil riset [6]. Serta penelitian kualitatif berupaya mendeskripsikan dan menginterprestasi objek sesuai dengan apa adanya.

Teknik pengumpulan data yang digunakan penulis dalam penelitian ini yaitu dengan observasi, wawancara dan studi pustaka.

1. Observasi

Penulis melakukan pengamatan serta mengkaji permasalahan secara langsung terhadap objek penelitian yaitu pelayanan peminjaman dan pengembalian rekam medis rawat jalan di Rumah Sakit Muhammadiyah Bandung.

2. Wawancara

Penulis melakukan wawancara atau interview dengan metode tanya jawab secara langsung terkait penelitian. Wawancara tersebut dilakukan kepada Kepala Unit Rekam Medis, petugas bagian Administrasi Umum Rekam Medis dan petugas Penyimpanan Rekam Medis tujuannya adalah untuk memperoleh informasi yang dibutuhkan mengenai sistem informasi peminjaman serta pengembalian rekam medis rawat jalan di Rumah Sakit Muhammadiyah Bandung.

3. Studi Pustaka

Penulis melihat dan mempelajari dari buku-buku ilmiah, jurnal, serta kajian-kajian pustaka lainnya yang ada kaitannya dengan variabel yang diteliti.

\section{Metode Pengembangan Perangkat Lunak}

Perancangan serta pembuatan sistem informasi menggunakan metode waterfall. Alasan peneliti menggunakan metode ini disebabkan adanya kesamaan dengan sifat penelitian yang dilakukan. Dalam pengembangannya metode waterfall mempunyai beberapa tahapan yang terstruktur: Requirements definition (analisis kebutuhan) dalam langkah ini adalah analisis terhadap keperluan sistem yang hendak membuat dokumen user requirement ataupun dapat dikatakan sebagai informasi yang berhubungan dengan kemauan user dalam perancangan sistem. System and software design (desain sistem) proses design bakal menerjemahkan ketentuan keperluan sebuah pembuatan perangkat 
lunak yang dapat diprediksi sebelum membuat coding. Langkah inilah yang hendak dipakai programmer untuk melaksanakan kreativitas perancangan sistemnya. Implementation and unit testing (pembuatan program) coding ialah penerjemahan desain kedalam isyarat yang dapat dipahami oleh komputer, sesudah pengkodean telah selesai dilakukan, selanjutnya akan dicoba testing atas sistem yang sudah dirancang. Testing dilakukan agar mengetahui kesalahan-kesalahan terkait sistem itu serta setelah itu dapat diperbaiki. Integration and system testing (penerapan program) tahapan ini dapat dilakukan diakhir dalam pembuatan sistem, sesudah melakukan analisis, design serta pengkodean hingga sistem telah dipakai oleh user. Operation and maintenance (pemeliharaan) setelah analisis, design serta pengkodean untuk itu sistem yang telah dibuat akan dijalankan oleh user. Selanjutnya software yang sudah jadi wajib dilakukan perawatan secara teratur [7] . Selain itu, metode ini harus diselesaikan tahap demi tahap yang artinya tidak dapat melompati ke tahap selanjutnya sebelum tahap yang sedang di kerjakan telah benar-benar selesai [7].

\section{HASIL DAN PEMBAHASAN}

Analisis proses ini untuk menggambarkan proses sistem informasi peminjaman dan pengembalian rekam medis rawat jalan di Rumah Sakit Muhammadiyah Bandung ialah sebagai berikut:

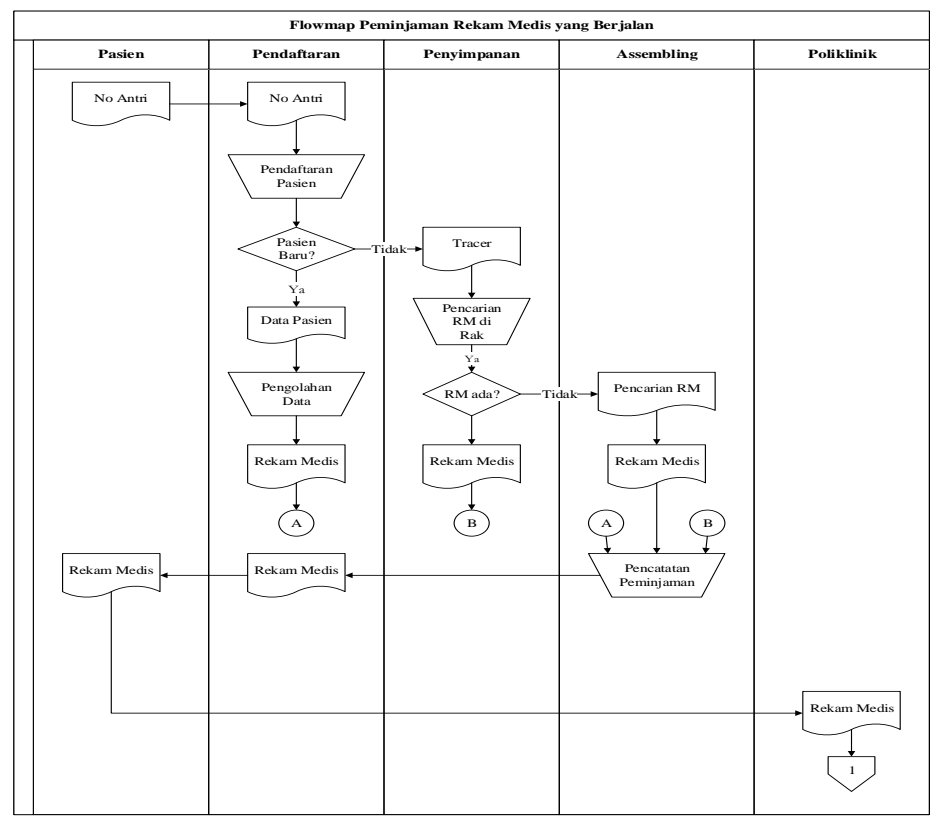

Sumber : Diolah Penulis, 2021

Gambar 1. Proses Peminjaman Rekam Medis 


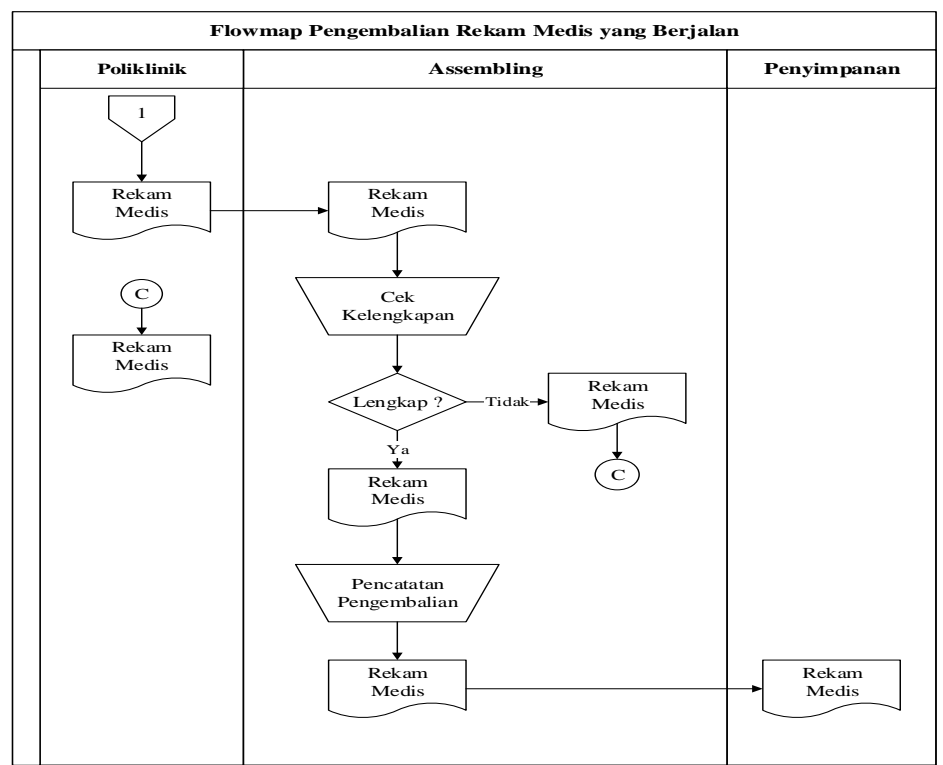

Sumber : Diolah Penulis, 2021

Gambar 2. Proses Pengembalian Rekam Medis

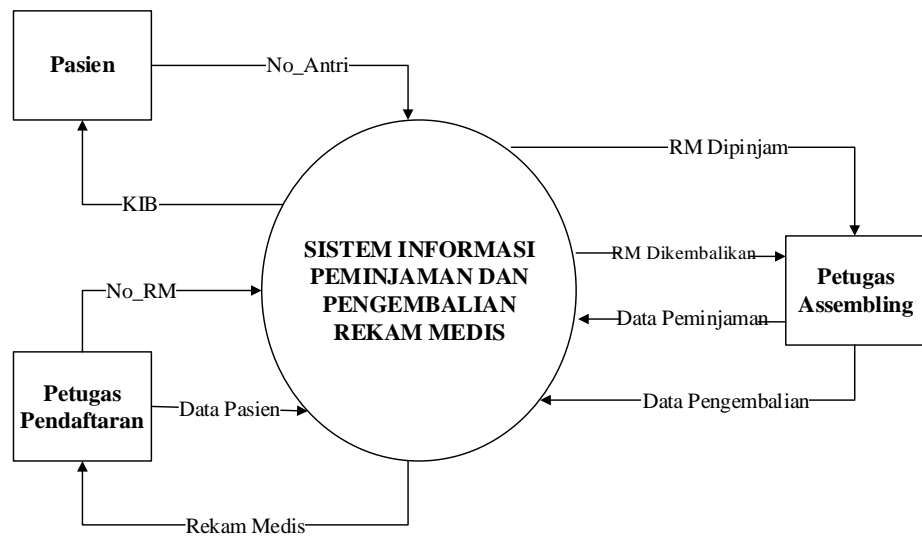

Sumber : Diolah Penulis, 2021

Gambar 3. Context Diagram Sistem yang Berjalan
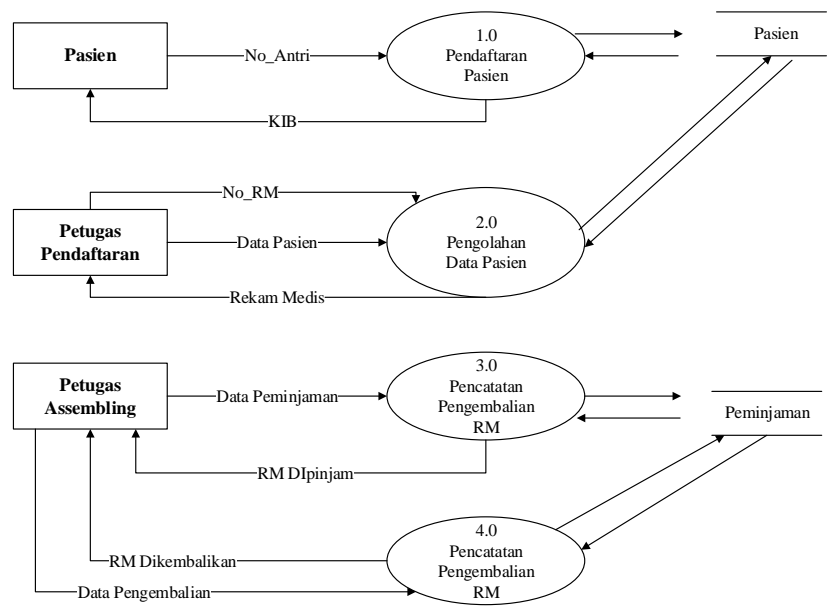

Sumber : Diolah Penulis, 2021

Gambar 4. DFD Level 0 Sistem yang Berjalan

\section{Perancangan Sistem}

Hasil analisis kebutuhan system di desain dalam bentuk flowchart system, context diagram, data flow diagram, dan entity relationship diagram. Flowmap yang disarankan 
pada perancangan sistem informasi peminjaman dan pengembalian rekam medis rawat jalan ialah sebagai berikut:

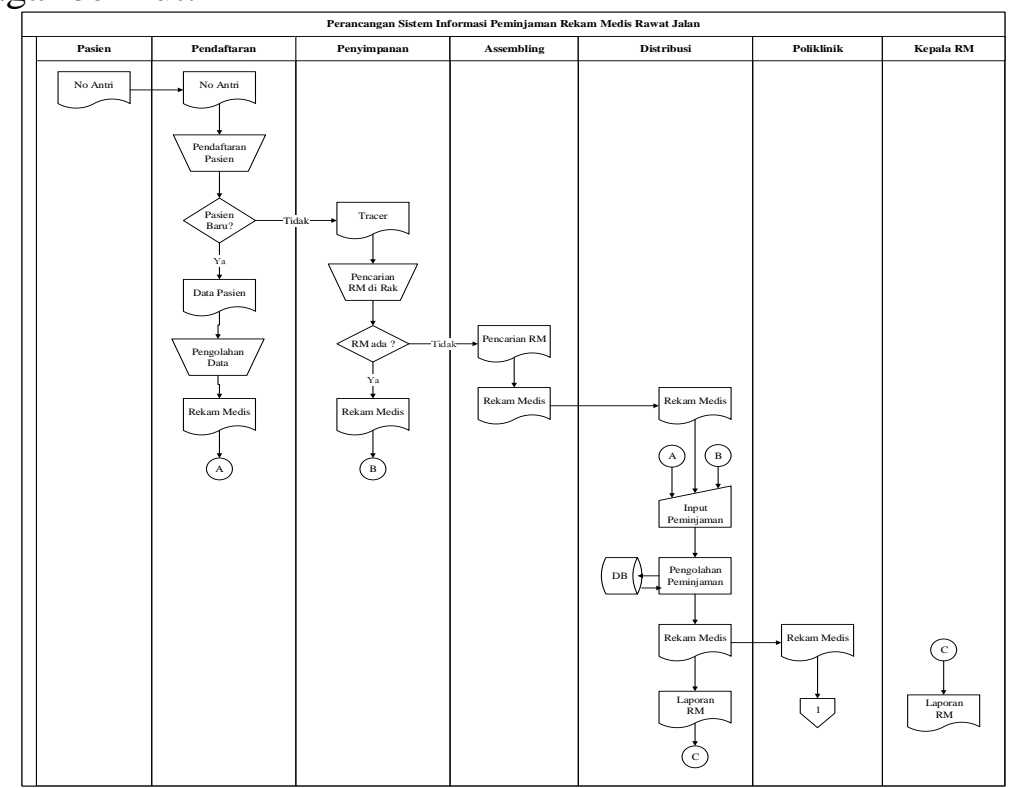

Gambar 5. Flowchart Sistem Peminjaman yang Dirancang

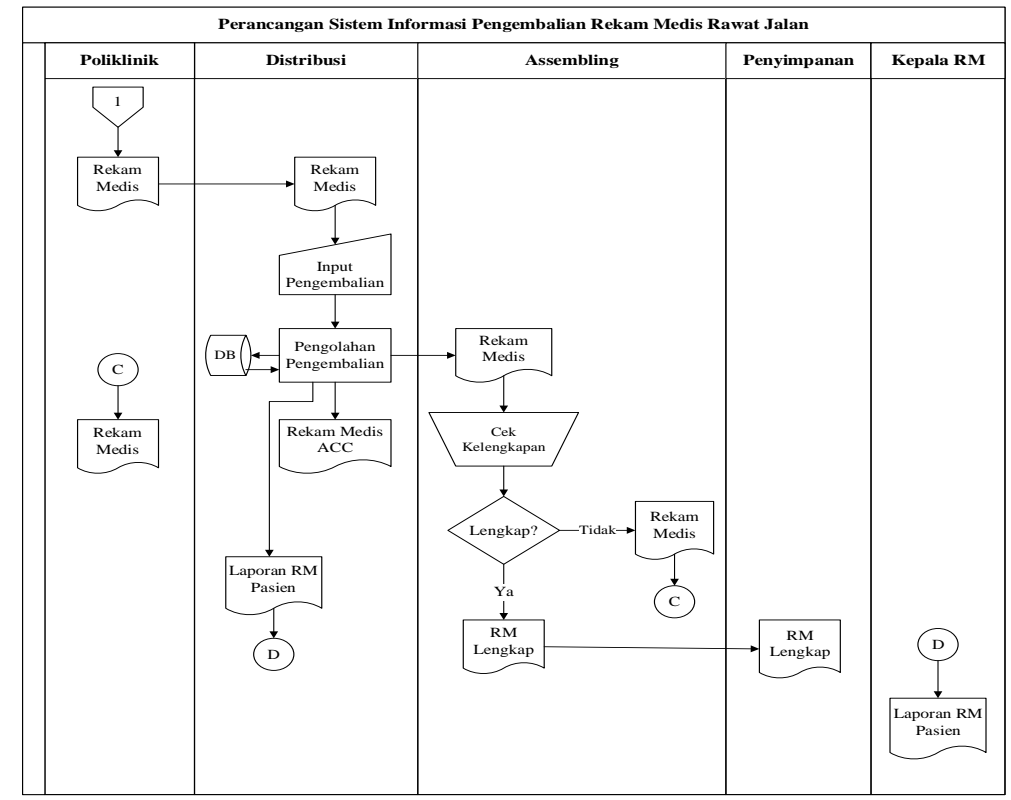

Gambar 6. Flowchart Sistem Pengembalian yang Dirancang 


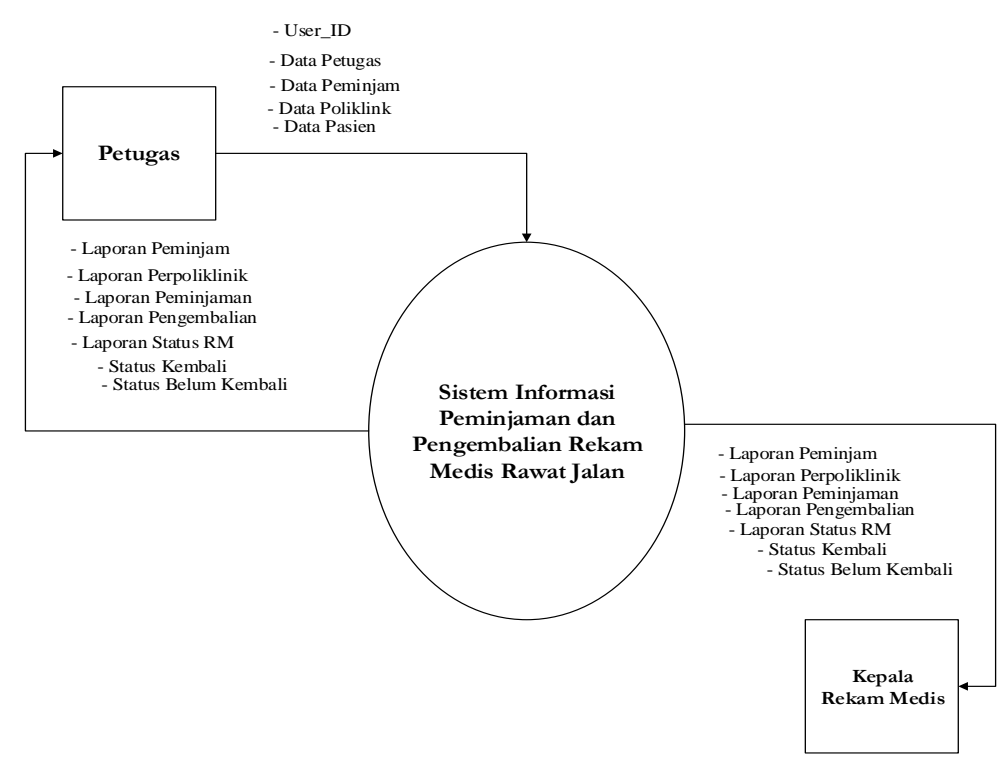

Gambar 7. Contex Diagram Sistem yang Dirancang

Dengan sistem ini petugas dan kepala Rekam Medis dapat mengakses sistem informasi dengan input user name dan password, input data petugas, input data peminjam, input data pasien serta transaksi peminjaman dan pengembalian. Dari hasil data petugas, data pasien serta transaksi peminjaman dan pengembalian dapat melihat laporan status rekam medis yang sudah kembali dan belum kembali, serta dapat mencetak laporan [8].

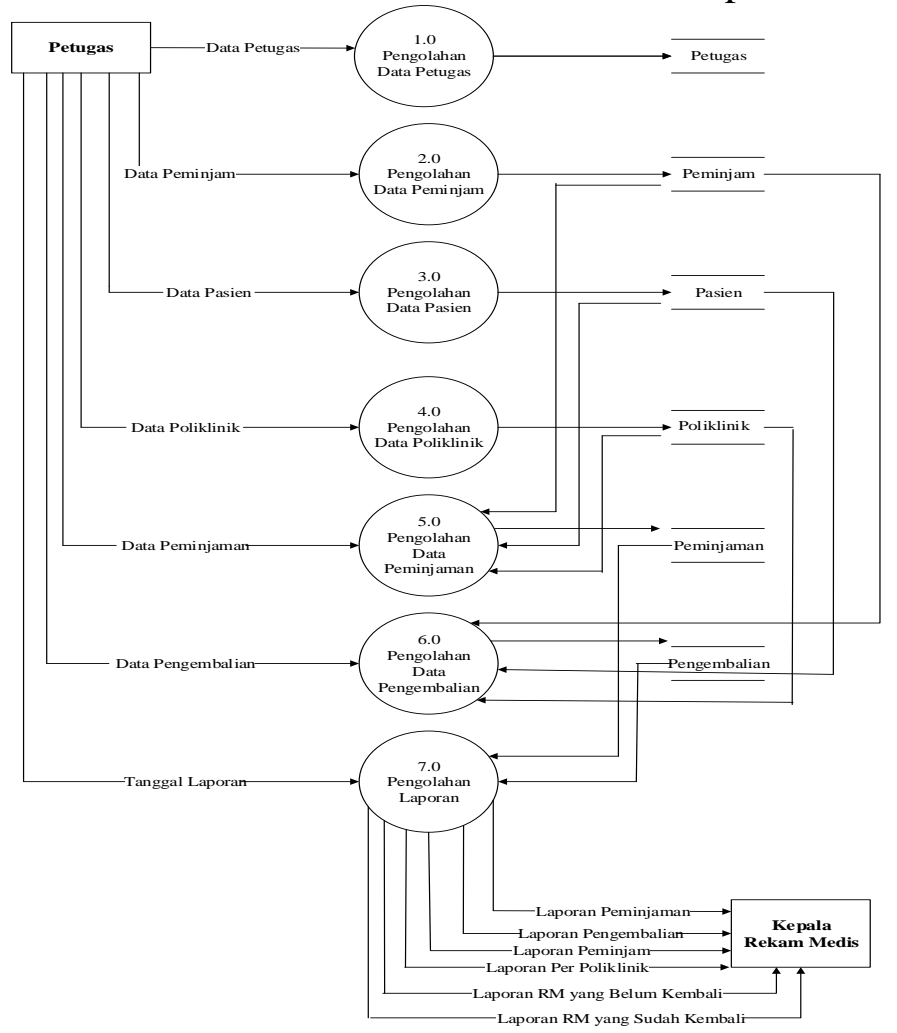

Gambar 8. DFD Sistem yang Dirancang

\section{Perancangan Basis Data}

Perancangan basis data ini dirancang untuk membentuk suatu lokasi penyimpanan data pada media penyimpanan. Pada rancangan ini untuk menggambarkan struktur tabel serta hubungan pada database penyimpanan. ERD adalah ikatan antara entitas yang digunakan dalam system informasi untuk menggambarkan ikatan antara entitas data dan ikatan antar 
file [3]. Bentuk entity relationship diagram dari sistem informasi peminjaman dan pengembalian rekam medis rawat jalan yang dirancang adalah sebagai berikut:

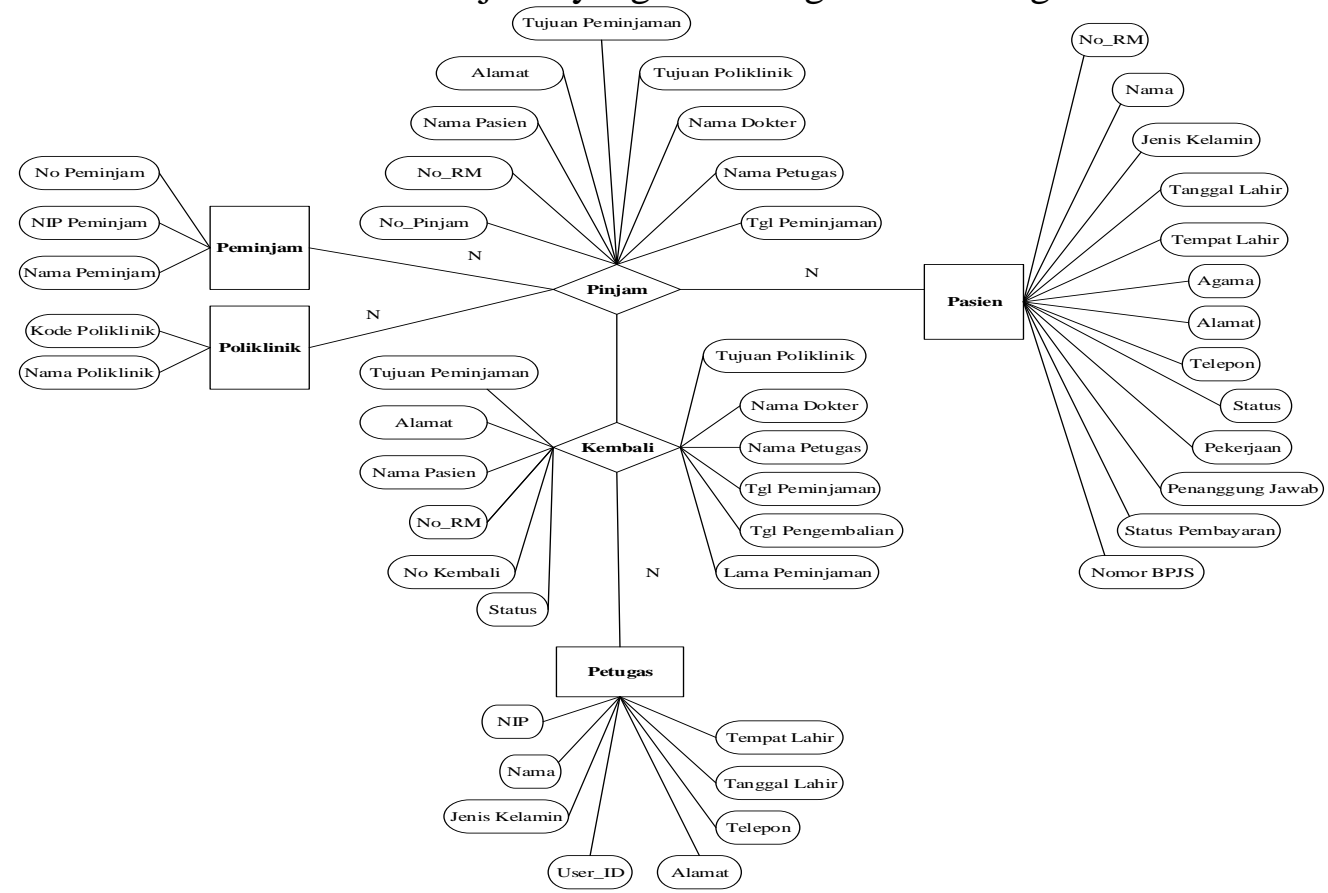

Gambar 9. Entity Relationship Diagram

\section{Implementasi Dan Pengujian Sistem}

Pengkodean sistem adalah proses pengkodean yang dilakukan dari proses desain yang telah dibuat selanjutnya diterapkan ke dalam sebuah program [5]. Pengkodean yang dilakukan pada tahap ini menggunakan aplikasi Microsoft Visual Studio 2010 dan penyimpanan database Microsoft Accsess 2013.

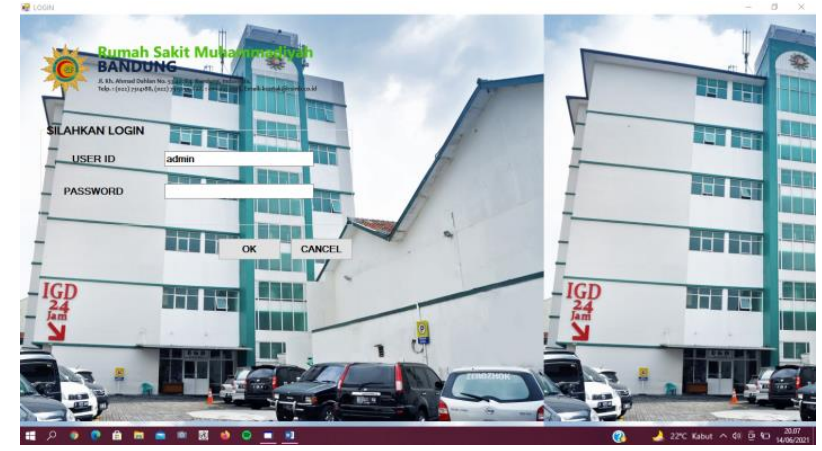

Gambar 11. Menu Login

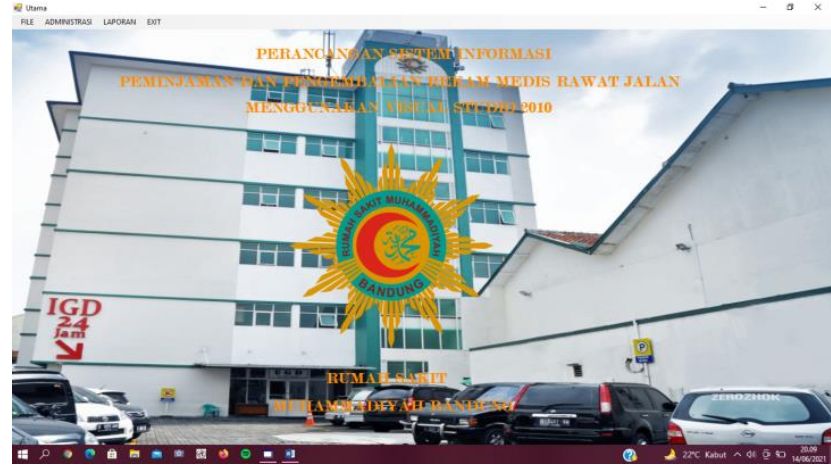

Gambar 12. Menu Utama 


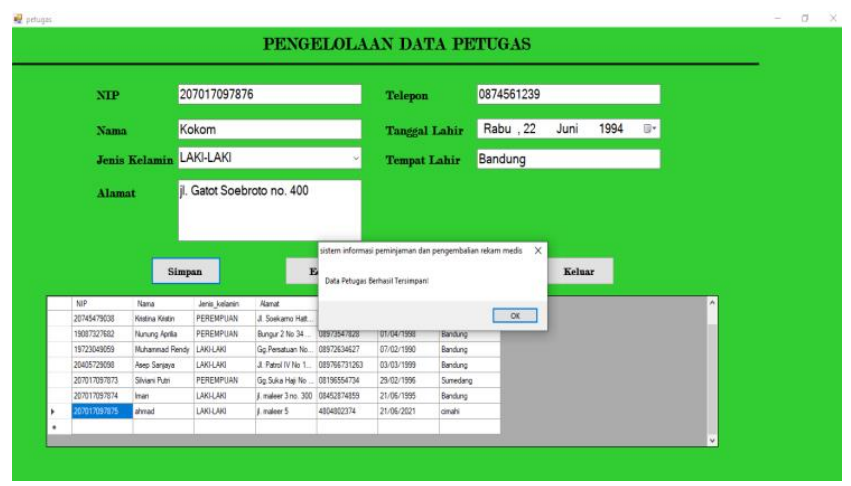

Gambar 13. Menu Petugas

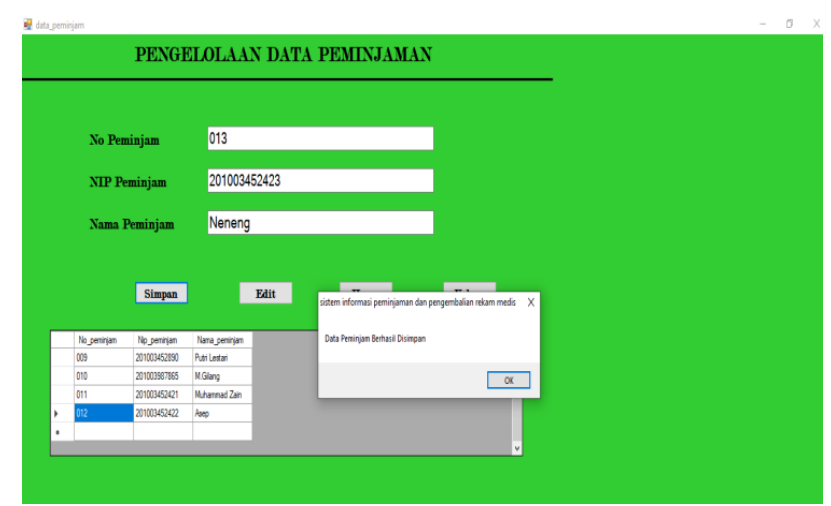

\section{Gambar 14. Menu Peminjam}

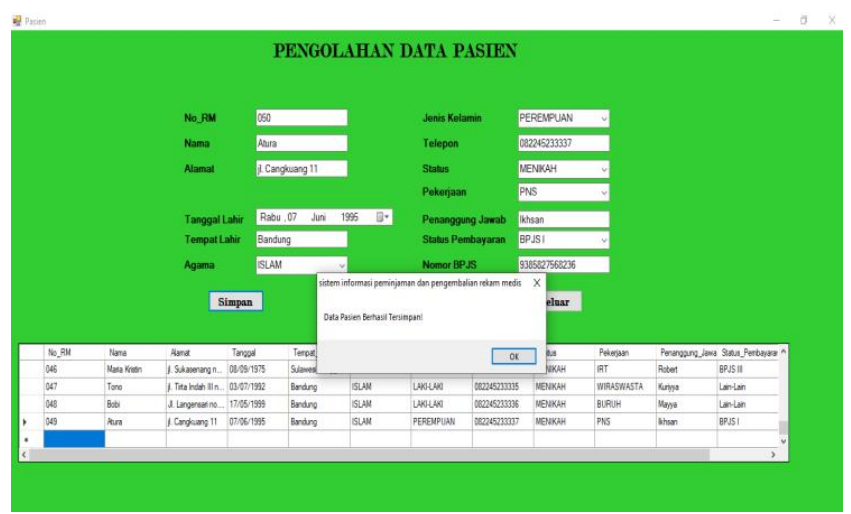

Gambar 15. Menu Pasien

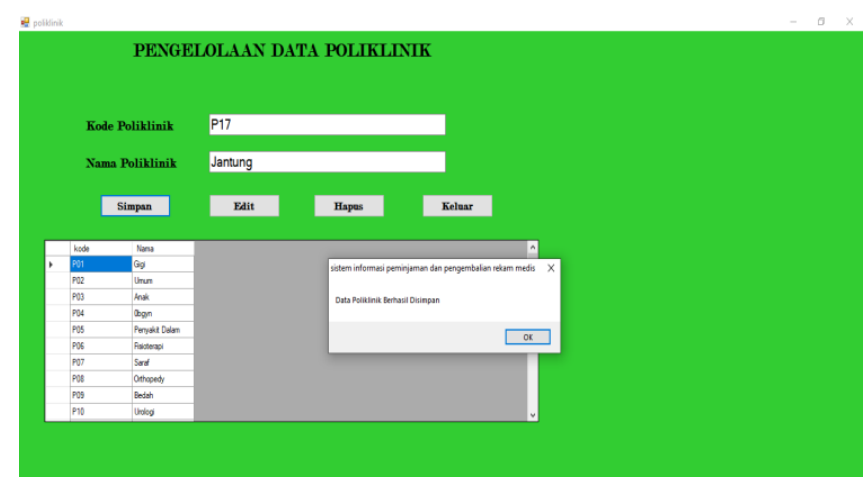

Gambar 16. Menu Poliklinik 


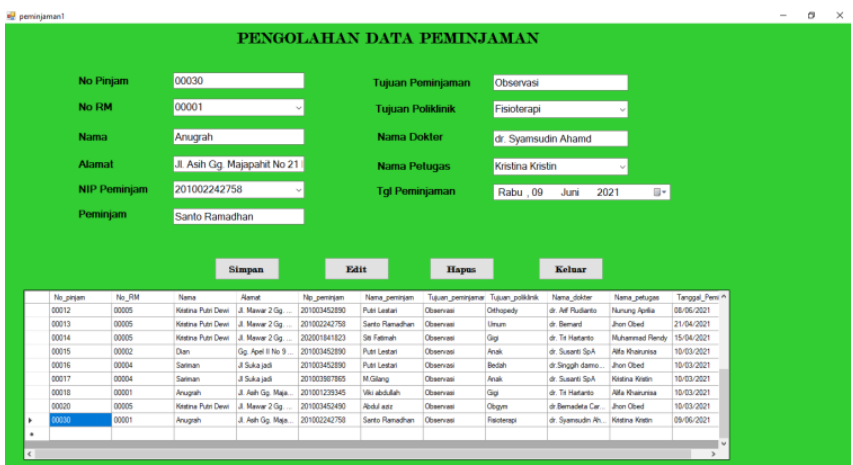

Gambar 17. Menu Peminjaman

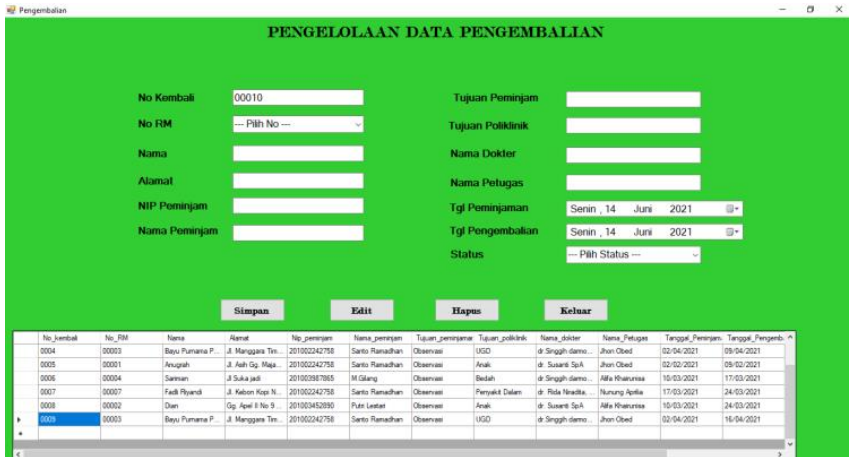

Gambar 18. Menu Pengembalian

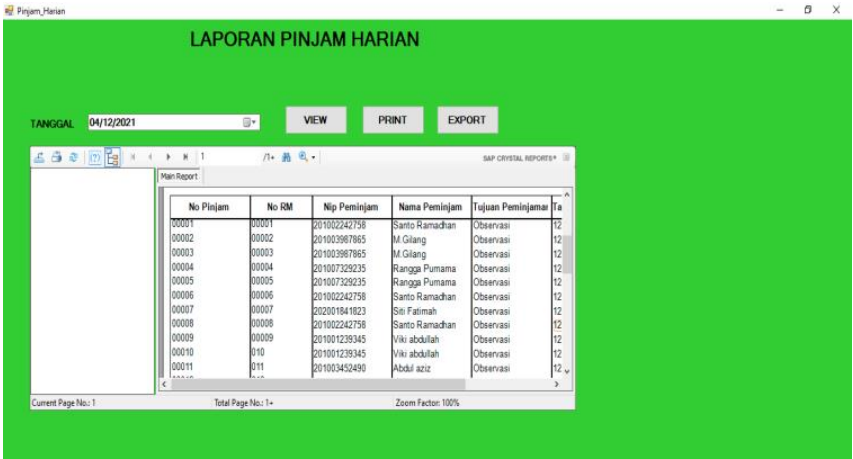

Gambar 19. Menu Laporan Peminjam

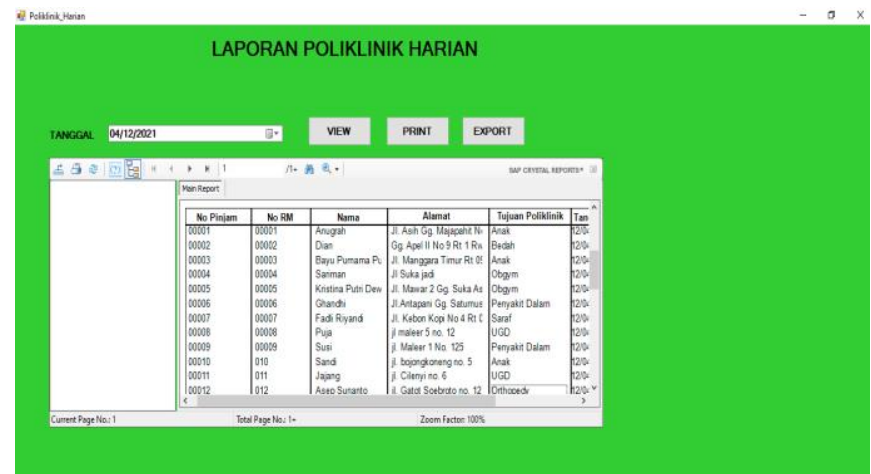

Gambar 20. Menu Laporan Poliklinik 


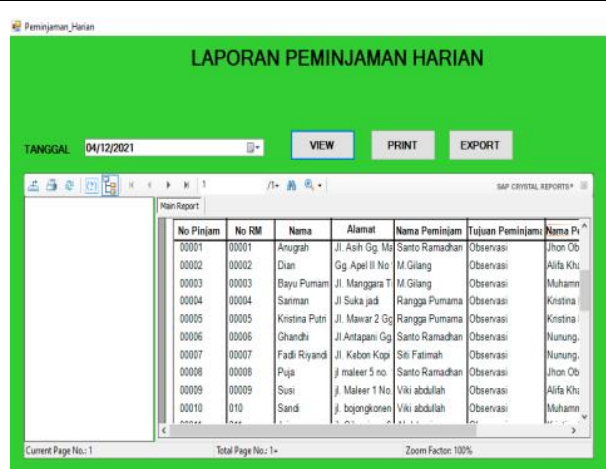

Gambar 21. Menu Laporan Peminjaman

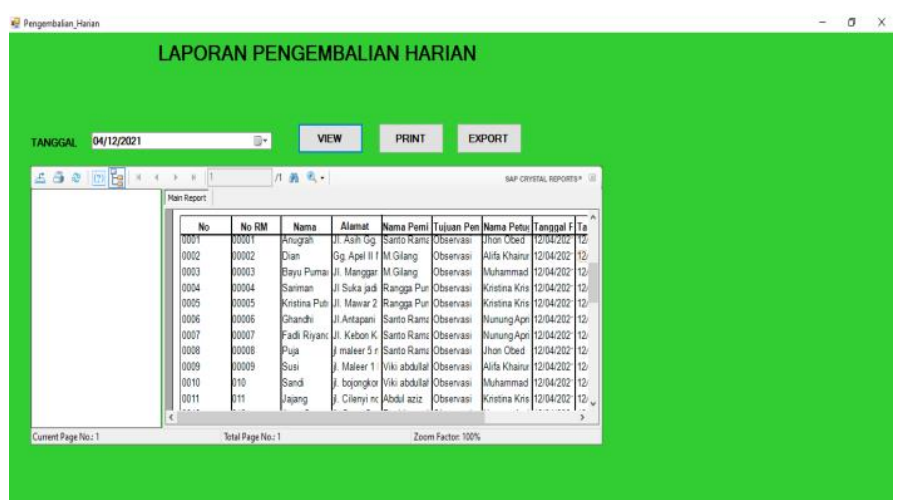

Gambar 22. Menu Laporan Pengembalian

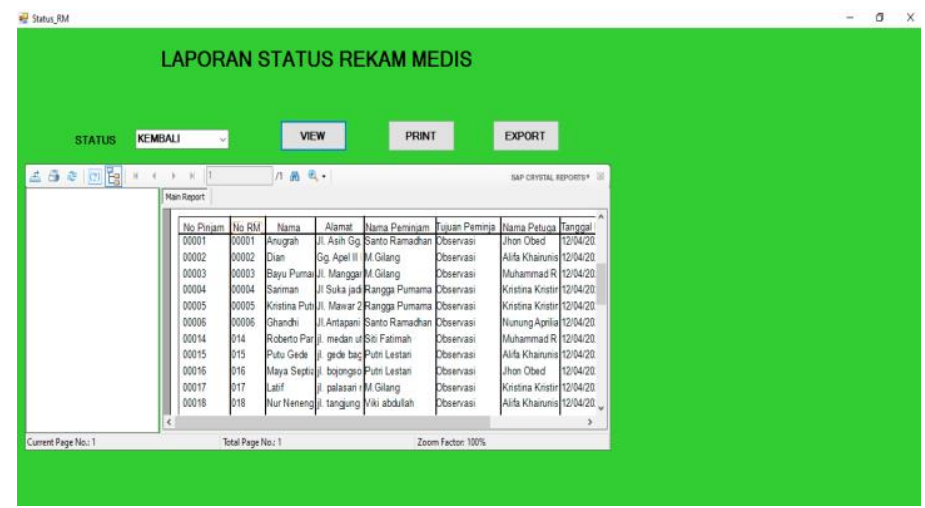

Gambar 23. Menu Status RM Kembali

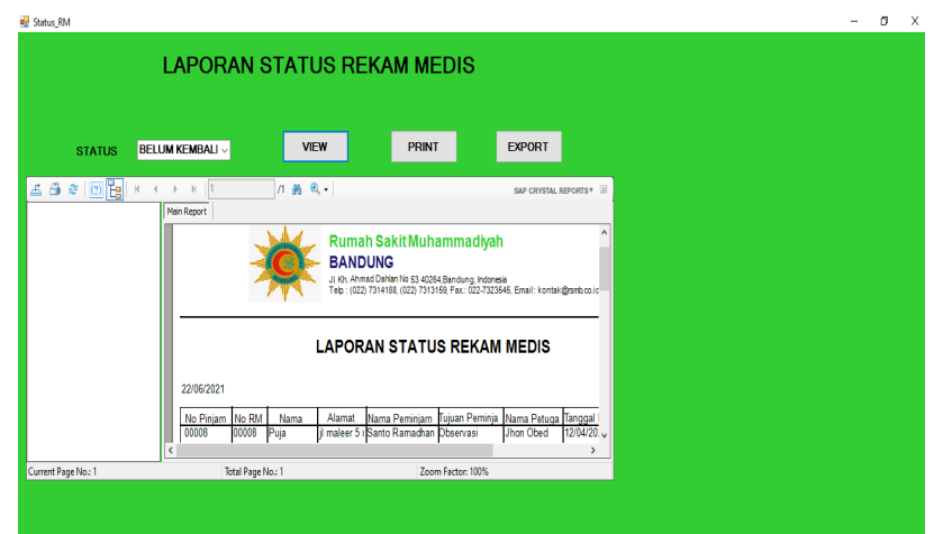

Gambar 24. Menu Status RM Belum Kembali 


\section{KESIMPULAN}

Kesimpulan dari hasil pembahasan dan perancangan sistem informasi peminjaman serta pengembalian rekam medis adalah sebagai berikut:

1. Berdasarkan hasil analisis kebutuhan (requirements definition) penulis mendapatkan data yang diperlukan oleh Rumah Sakit Muhammadiyah Bandung telah sesuai dengan kebutuhan sistem informasi.

2. Mendesain (System and Software Design) di desain dengan cara merancang flowchar tsistem, context diagram, data flow diagram, dan entity relationship diagram.

3. Pembuatan program (Implementation and unit testing) dilakukan menggunakan aplikasi pemrograman Microsoft Visual Studio 2010 dan penyimpanan database menggunakan Microsoft Access 2013

4. Mengaplikasikan percobaan sistem (Intergration and system testing) dilakukan dengan penerapan serta pengujian terhadap input (masukan) dan output (keluaran) memakai blackbox testing. Hasil pengujian sistemi nformasi ini sukses serta tidak ada error.

5. Hak akses petugas, sistem informasi peminjaman dan pengembalian rekam medis rawat jalan tidak semua orang bias mengaksesnya hanya petugas rawat jalan dan kepala rekam medis rumah sakit Muhammadiyah Bandung.

6. Sistem informasi ini terintegrasi dengan aplikasi SIMRS sehingga mempermudah untuk pengecekan riwayat kunjungan pasien serta memudahkan petugas dalam proses peminjaman dan pencarian rekam medis yang tidak ditemukan dalam ruang penyimpanan sehingga proses peminjaman dan pengembalian rekam medis dapat terkontrol dengan baik.

\section{REFERENCES}

[1] UU RI, "Undang-undang Republik Indonesia Nomor 44 Tahun 2009," Acta Universitatis Agriculturae et Silviculturae Mendelianae Brunensis, vol. 53, no. 9. Jakarta, pp. 1689-1699, 2009, [Online]. Available: http://publications.lib.chalmers.se/records/fulltext/245180/245180.pdf\%0Ahttps://hdl .handle.net/20.500.12380/245180\%0Ahttp://dx.doi.org/10.1016/j.jsames.2011.03.00 3\%0Ahttps://doi.org/10.1016/j.gr.2017.08.001\%0Ahttp://dx.doi.org/10.1016/j.preca mres.2014.12.

[2] PERMENKES RI No 269/MENKES/PER/III/2008, “permenkes ri 269/MENKES/PER/III/2008," Permenkes RI No 269/Menkes/Per/III/2008, vol. 2008. p. 7, 2008.

[3] S. Setiatin and Y. Syahidin, "Perancangan Sistem Informasi Penyimpanan Rekam Medis Rawat Inap Berbasis Elektronik," J. Manaj. Inf. Kesehat. Indones., vol. 5, no. 2, pp. 181-194, 2017.

[4] Putri Liza Amalia; Santi Maya Weka Santi; Wijayanti Rossalina Adi, "Perancangan Sistem Informasi Peminjaman Dan Pengembalian Brm Rawat Jalan Di Rumah Sakit Husada Utama," J. Rekam Med. Dan Inf. Kesehat., vol. 1, no. 3, pp. 288-296, 2020.

[5] S. Farlinda, R. Nurul, and S. A. Rahmadani, "Pembuatan Aplikasi Filling Rekam Medis Rumah Sakit ISSN : 2354-5852," Kesehatan, vol. 5, no. 1, pp. 8-13, 2017.

[6] Kasmawati, "Pengaruh Lingkungan Kerja terhadap Kinerja Karyawan pada PT. Sermani Steel Makassar,” p. 66, 2014.

[7] A. Putri Wijayanti et al., "PERANCANGAN SISTEM INFORMASI KOHORT IBU HAMIL MENGGUNAKAN MICROSOFT VISUAL STUDIO 2010 DI UPT PUSKESMAS PASEH KABUPATEN BANDUNG," bandung, 2020.

[8] N. M. Jamil, N. Muna, R. A. Wijayanti, A. P. Wicaksono, J. Kesehatan, and P. N. Jember, "Sistem Informasi Peminjaman Dan Pengembalian Dokumen Rekam Medis 
Menggunakan Metode Waterfall (Studi Kasus Puskesmas," J-REMI J. Rekam Med. Dan Inf. Kesehat., vol. 1, no. 2, pp. 94-103, 2020.

\section{BIOGRAPHIES OF AUTHORS}

\begin{tabular}{|l|l|}
\hline & $\begin{array}{l}\text { Israwati. Penulis merupakan mahasiswa tingkat akhir Program Studi D3 Rekam Medis } \\
\text { dan Informasi Kesehatan. Aktif dalam organisasi Himpunan Mahasiswa Rekam Medis } \\
\text { dan Informasi Kesehatan di Politeknik Piksi Ganesha Bandung. Lulus SD pada tahun } \\
2012 \text { di MI Muhammadiyah Wuring, lulus SMP pada tahun 2015 di MTs } \\
\text { Muhammadiyah Wuring, dan lulus SMA pada tahun 2018 di MA Muhammadiyah } \\
\text { Nangahure. }\end{array}$ \\
\hline & $\begin{array}{l}\text { Sali Setiatin. Penulis merupakan dosen tetap Politeknik Piksi Ganesha Bandung } \\
\text { Program Studi Rekam Medis dan Informasi Kesehatan. Gelar D3 Rekam Medis dan } \\
\text { Informasi Kesehatan diperoleh dari Politeknik Piksi Ganesha Bandung lulus pada tahun } \\
\text { 2006. Gelar S1 Informatika Rekam Medis diperoleh dari Politeknik Piksi Ganesha } \\
\text { Bandung lulus pada tahun 2011, dan gelar S2 diperoleh dari STIMA IMMI Jakarta lulus } \\
\text { pada tahun 2015. }\end{array}$ \\
\hline & $\begin{array}{l}\text { Falaah Abdussalaam. Penulis merupakan dosen tetap Politeknik Piksi Ganesha } \\
\text { Bandung Program Studi Sistem Informasi DIV. Gelar S1 Manajemen Sistem Informasi } \\
\text { diperoleh dari Politeknik Piksi Ganesha Bandung lulus pada tahun 2009, dan S2 } \\
\text { Manajemen Sistem Informasi diperoleh dari STIMA IMMI Jakarta lulus pada tahun } \\
\text { 2011. }\end{array}$ \\
\hline
\end{tabular}

